Article

\title{
An Environmental Approach to Understanding the Expansion of Future Vineyards: Case Study of Soil Developed on Alluvial Sediments
}

\author{
Raimundo Jiménez-Ballesta ${ }^{1}\left(\mathbb{D}\right.$, Sandra Bravo ${ }^{2} \mathbb{D}$, Jose Angel Amorós ${ }^{2} \mathbb{0}$, Caridad Pérez-de-los-Reyes ${ }^{2}$, \\ Jesus García-Pradas ${ }^{2}$, Monica Sánchez ${ }^{2}$ and Francisco Jesús García-Navarro ${ }^{2, *(D)}$ \\ 1 Department of Geology and Geochemistry, Autonomuos University of Madrid, 28019 Madrid, Spain; \\ raimundo.jimenez@uam.es \\ 2 Higth Technical School of Agricultural Engineers, University of Castilla-La Mancha, 13007 Ciudad Real, Spain; \\ sandra.bravo@uclm.es (S.B.); joseangel.amoros@uclm.es (J.A.A.); caridad.perez@uclm.es (C.P.-d.-l.-R.); \\ jesus.garciapradas@uclm.es (J.G.-P.); monica.sanchez@uclm.es (M.S.) \\ * Correspondence: fcojesus.garcia@uclm.es
}

check for updates

Citation: Jiménez-Ballesta, R.; Bravo, S.; Amorós, J.A.; Pérez-de-los-Reyes,

C.; García-Pradas, J.; Sánchez, M.;

García-Navarro, F.J. An

Environmental Approach to

Understanding the Expansion of Future Vineyards: Case Study of Soil Developed on Alluvial Sediments. Environments 2021, 8, 96. https:// doi.org/10.3390/environments8090096

Academic Editor: Vernon Hodge

Received: 12 August 2021

Accepted: 15 September 2021

Published: 17 September 2021

Publisher's Note: MDPI stays neutral with regard to jurisdictional claims in published maps and institutional affiliations.

Copyright: (c) 2021 by the authors. Licensee MDPI, Basel, Switzerland. This article is an open access article distributed under the terms and conditions of the Creative Commons Attribution (CC BY) license (https:/ / creativecommons.org/licenses/by/ $4.0 /)$.
Abstract: The importance of soil properties in wine grape production is generally treated as secondary to climate and canopy management. This study was undertaken to characterize and classify a singular soil resource for a vineyard in a traditional viticultural region: Castilla-La Mancha, central Spain. The soil under study was described and sampled using standard soil survey procedures as outlined by FAO, and served as a pedologic window for Gleyic Fluvisol (Calcaric, Humic), according to the FAO System, or Fluventic Haploxerept, according to the Soil Taxonomy System. This soil, developed on alluvial materials of Holocene age related to the Gigüela river (either carbonatic or gypsiferous) has, in addition to obvious hydromorphic features (that reduce its use), high organic matter content (5.5\% in the Ap horizon) and moderate salt content (between 1.14 and $2.39 \mathrm{dS} / \mathrm{m}$ ). Other properties are common to most vineyard soils in Castilla-La Mancha, such as alkaline reactivity ( $\mathrm{pH}$ between 7.6 and 8.2); calcium and magnesium as the dominant cations followed by sodium and potassium; finally, some deficiency in $\mathrm{N}(0.11 \%)$ and $\mathrm{P}(12.3 \mathrm{mg} / \mathrm{kg})$. The most restricting soil factors for vineyard growth of this soil type were waterlogging, which can affect vine roots, and the appearance of certain salinity problems. The final conclusion of this study was that the use of the studied soil type for vineyard cultivation could be recommended to farmers only in the case of improving soil properties-for example, draining the river level.

Keywords: soil survey; morphological characteristics; chemical characteristics; pedon; semiarid environment; Gleyic Fluvisols; sustainable vineyard production; agricultural sustainability; terroir

\section{Introduction}

Although sustainable agricultural intensification has attracted worldwide attention, according to Hualin et al. [1], the improvement in the multifunctional properties of lands is crucial to meeting the needs of developing economies.

Wine is a pillar of history, tradition and culture. It is also an essential component of the valued Mediterranean diet, as is the case with olive oil. In Mediterranean environments, leaching and the accumulation of carbonates, clay illuviation and rubefaction are some of the most common morphological soil features to have been widely reported $[2,3]$.

Castilla-La Mancha is a major vineyard-producing area in Spain. Understanding the soil-limiting factors that affect the production of grapevines would help policy makers manage the sustainable planning and management of soils. In our studies on soils in Castilla-La Mancha, we observed that calcium carbonate accumulation, rubefaction and clay illuviation occurred as the main pedological processes [4,5]. Many soils in the region have not had their potential exploited; as such, there is plenty of room for improvement. 
However, other soils did not seem to meet the minimum requirements of those dedicated to viticultural activity. For example, in Castilla-La Mancha, where almost 53\% of soils are already in use, some areas have traditionally been neglected by farmers, as they were aware that the success of the crops was limited. This is the case in depressed areas with practically flat terrain, such as in Castilla-La Mancha, or in fluvial areas or areas bordering the course of rivers.

The current annual production of wine in Castilla-La Mancha is around 25 million hl. [6], but the potential is likely higher due to the semiarid, sunny Mediterranean climate. Although insufficient water is a problem, new technologies, such as drip irrigation, are being developed through agricultural research. Other soils are at risk of flooding, which is why they frequently present hydromorphic features in their edaphic profiles.

Sustainable agriculture strives to maintain or even increase productivity, quality and economic viability, while leaving a minimal footprint on the environment [7]. Dubey et al. [8] stated that the development of suitable packages of integrated agronomic practices was essential for agricultural sustainability. Many studies related to land suitability for vineyard cultivation have been conducted in different areas ([3-5,9-15]. Indeed, soil is a key component of wine production [16,17]. Although vines can grow in several soil types, they grow in several textural classes, within a wide range of $\mathrm{pH}$ levels, from moderately acidic (5.6) to moderately alkaline (8.5), and in well-drained, calcareous (or not calcareous) soils. Sometimes, limiting factors occur, such as shallow soil depth or salinity, which constrain the normal development of a vineyard.

The geology and geomorphology of the studied territory are local geographical features that serve as natural ecological resources. Many studies have been carried out on the relationship between soils and geomorphic surfaces [18,19]. Well-drained and moderately well-drained soils dedicated to vineyards predominate in Castilla-La Mancha [4]. Only a few small zones of this region are imperfectly or poorly drained; they occupy endorheic depressions or weakly dissected fluvial terraces (Pleistocene and Holocene overlaying Miocenic geological materials). A representative pedon of this potentially waterlogged area was studied for its morphological, physical, physicochemical and chemical properties. Thus, the specific objectives of this study were to (a) assess the main characteristics of a soil developed on an alluvial material of Holocene age related to the Cigüela river catchment, and (b) to determine the suitability of this type of soil for the cultivation of grapevines while identifying the environmental factors affecting vineyard growth.

\section{Materials and Methods}

The studied soil profile was located within the boundaries of the Province of Toledo (specifically, in the eastern end) and within the Castilla-La Mancha region of Spain (Figure 1). The topography was practically flat, with an altitude that ranged between 700 and $800 \mathrm{~m}$ above sea level. Lithologically, the area was dominated by Mesozoic and Cenozoic (Paleogene, Neogene and Quaternary periods) sedimentary rocks. The alluvial and valley bottom deposits of the Cigüela River and its tributaries were made up of sands, silts and clays. The climate was Mediterranean, with moist and cool winters, and warm and dry summers. The average annual temperature approached $13.3^{\circ} \mathrm{C}$ and annual rainfall was about $497 \mathrm{~mm}$. In general, the frost-free period lasted less than 180 days, which is the time required to guarantee an adequate cycle of growth and development of the vine. 

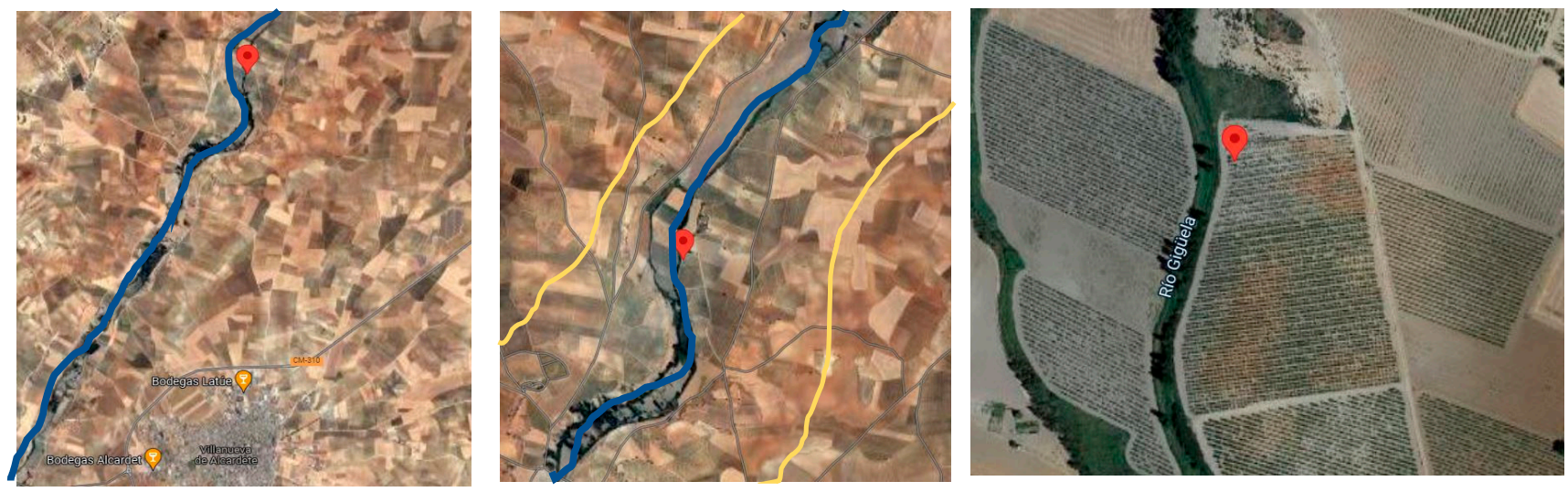

Figure 1. Location of the soil profile, derived from Google Earth. The blue line indicates the Cigüela river and the yellow line shows the area, with the presence of redox conditions. Soil profile situated at $\mathbf{D}$.

The land use/land cover map and soil map were used by Garcia-Navarro et al. [20] to plan soil sampling in the studied area. At this stage, the area was traversed and, with the help of a machine, 15 profiles were opened. The spatial data were made uniform and GPS-located, based on satellite images of high spatial resolution. The selected soil profile (Figure 2) was excavated to a depth of approximately $1.5 \mathrm{~m}$ to obtain a full description according to the FAO criteria [21]. The parent material of this soil was alluvium with limited distinct alluvial discontinuities. The soil was considered imperfectly drained and contained redoximorphic features in the lower horizons with a reduced matrix. The Munsell colors of the soil horizons ranged from $2.5 \mathrm{Y} 6 / 1$ at the $C_{\mathrm{g} 1}(83-111 \mathrm{~cm})$ to $2.5 \mathrm{Y} 7 / 3$ at the $\mathrm{C}_{\mathrm{g} 2}$ $(>111 \mathrm{~cm}$ ) horizon (Table 1). This effect was the result of endosaturation, which occurs when soil is saturated with water in one or more layers within approximately $100 \mathrm{~cm}$ of the mineral soil surface. Naturally, under saturated conditions, aerobic microorganisms consume all the available oxygen, while anaerobic ones metabolize and reduce Fe. The main vine variety was Tempranillo.

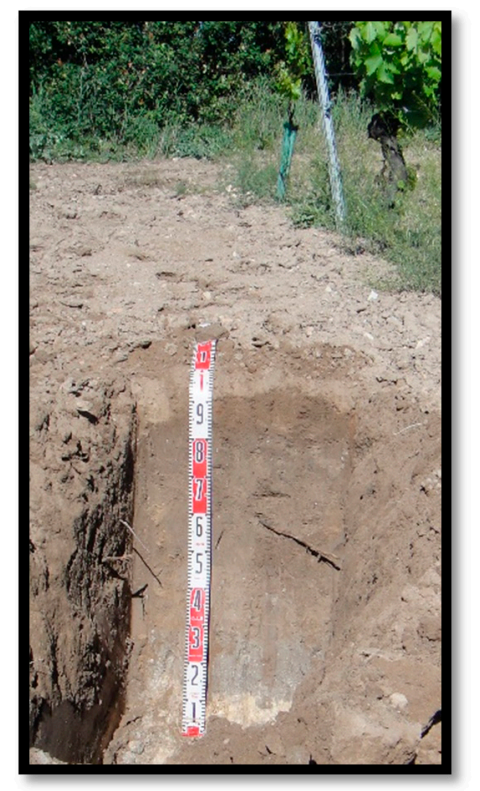

Figure 2. View of the selected soil profile. 
Table 1. General description and macromorphological characteristics of the researched soil (Villanueva de Alcardete, Toledo).

\begin{tabular}{|c|c|c|c|c|c|c|c|}
\hline $\begin{array}{l}\text { Soil Type } \\
\text { FAO/Soil } \\
\text { Taxonomy }\end{array}$ & $\begin{array}{l}\text { Location } \\
\text { Coordinates }\end{array}$ & Altitude (m) & Parent Material & Vegetation Use & $\begin{array}{l}\text { Geomorphic } \\
\text { Surface }\end{array}$ & Slope & Drainage \\
\hline $\begin{array}{c}\text { Gleyic Fluvisol } \\
\text { (Calcaric, Humic)/ } \\
\text { Fluventic } \\
\text { Haploxerept }\end{array}$ & $\begin{array}{l}\text { GPS: } 39^{\circ} 42^{\prime} 29.0^{\prime \prime} \\
\text { (N)-03 } 03^{\circ} 46.0^{\prime \prime}(\mathrm{W}) \\
\text { UTM: }(30 \mathrm{~s}) 0498908 \\
\text { (x)-4395356 (y) }\end{array}$ & 715 & $\begin{array}{l}\text { Fluvial loamy } \\
\text { sediments }\end{array}$ & $\begin{array}{c}\text { Vineyard } \\
\text { (Tempranillo) }\end{array}$ & $\begin{array}{l}\text { Alluvial } \\
\text { floodplain }\end{array}$ & Flat & $\begin{array}{l}\text { Imperfectly } \\
\text { drained }\end{array}$ \\
\hline $\begin{array}{l}\text { Horizons/ } \\
\text { Depth }(\mathrm{cm})\end{array}$ & Color (dry) & Structure & Consistence & Roots & Pores & Limit & $\begin{array}{l}\text { Stoniness } \\
\quad(\%)\end{array}$ \\
\hline Ap (0-35) & $\begin{array}{l}10 \text { YR 5/3 (d) } \\
10 \text { YR 4/3 (w) }\end{array}$ & $\begin{array}{c}\text { Blocky } \\
\text { subangular } \\
\text { thick }\end{array}$ & $\begin{array}{c}\text { Slightly sticky, } \\
\text { no plastic, } \\
\text { loose and slightly hard }\end{array}$ & Few fines & $\begin{array}{l}\text { Common } \\
\text { fines }\end{array}$ & $\begin{array}{l}\text { Gradual and } \\
\text { wavy }\end{array}$ & 5 \\
\hline $\mathrm{Bw}(35-83)$ & $\begin{array}{l}10 \mathrm{YR} 4 / 3 \\
(\mathrm{~d} \text { and } w)\end{array}$ & Massive & $\begin{array}{c}\text { Slightly sticky, } \\
\text { slightly plastic, } \\
\text { loose and slightly hard }\end{array}$ & Few & $\begin{array}{l}\text { Few, } \\
\text { all sizes }\end{array}$ & $\begin{array}{l}\text { Diffuse and } \\
\text { wavy }\end{array}$ & 2 \\
\hline Cg1 (83-111) & $\begin{array}{l}2.5 \mathrm{Y} 6 / 1(\mathrm{~d}) \\
2.5 \mathrm{Y} 5 / 1(\mathrm{w})\end{array}$ & Massive & $\begin{array}{l}\text { Slightly sticky, } \\
\text { slightly plastic, } \\
\text { firm and slightly hard }\end{array}$ & Without & $\begin{array}{l}\text { Few, } \\
\text { all sizes }\end{array}$ & Net and plane & 0 \\
\hline Cg2 (>111) & $\begin{array}{l}2.5 \text { Y } 7 / 3(\mathrm{~d}) \\
2.5 \text { Y } 6 / 2(\mathrm{w})\end{array}$ & Massive & $\begin{array}{l}\text { Very compact and } \\
\text { slightly hard }\end{array}$ & Without & $\begin{array}{l}\text { Few, } \\
\text { all sizes }\end{array}$ & Net and plane & 0 \\
\hline
\end{tabular}

d: dry; w: wet.

Soil samples were collected, naturally air-dried and sieved through a $2 \mathrm{~mm}$ sieve to remove the coarse fraction. The $<2 \mathrm{~mm}$ fraction was homogenized prior to chemical analysis. Specifically, soil $\mathrm{pH}$ was measured in water and in KCI $(\mathrm{c}=1 \mathrm{M})$ in a 1:2.5 soil-to-liquid ratio, using a combined glass electrode [22]. Organic $\mathrm{C}$ was determined by the Walkley-Black procedure [23]. Nitrogen was analyzed by Kjeldahl digestion [24]. Electrical conductivity was measured in water using a 1:5 soil-to-liquid ratio. Carbonate content was measured by the calcimeter method. Active limestones were determined with $\mathrm{NH}_{4}$-oxalate [25]. The cation exchange capacity (CEC) was determined by the NHOAc method [26]. Extraction with $0.5 \mathrm{M} \mathrm{NaHCO}_{3}$ was used to estimate available P [27]. Standard procedures were used in determining bulk density via the core method; the cores were extracted in the field and separated into $0-10 \mathrm{~cm}$ and $10-20 \mathrm{~cm}$ soil depths [28]. Texture was determined by the touch texture method, given the difficulties of achieving dispersion. Analytical precision was controlled by repeating the analysis of individual samples three times until it was satisfactory (relative standard deviation $<5 \%$ ).

\section{Results}

The soil characterization profile description and analytical characterization of the selected soil profile are summarized in Tables 1 and 2 and Figure 3 . Vineyard soils require good drainage to improve or sustain production, or to manage water supplies. Nevertheless, field observations confirmed the presence of poor drainage conditions. The slope (geomorphic) position had significant effects on properties, e.g., saturated soil moisture. The soil textural classes were silty loam in all soil horizons. The bulk density values varied between $0.90 \mathrm{~g} / \mathrm{cm}^{3}$ and $1.46 \mathrm{~g} / \mathrm{cm}^{3}$. An ideal bulk density for root growth, based on sandy loams and loam-textural soils, should be lower than $1.40 \mathrm{~g} / \mathrm{cm}^{3}$ [29]. From the $A_{p}$ to $C_{g 2}$ horizons, the $\mathrm{pH}$ values of the soil samples varied within the limits of a moderately alkaline soil, and were approximately 7.6 to 8.2. The electrical conductivity of the soil horizons varied between $1.14 \mathrm{dS} / \mathrm{m}$ ( $\mathrm{C}_{\mathrm{g} 2}$ horizon) and $2.38 \mathrm{dS} / \mathrm{m}\left(\mathrm{C}_{\mathrm{g} 2}\right.$ horizon). The soil samples had a lime content ranging from moderately $\left(10.5 \%, \mathrm{C}_{\mathrm{g} 2}\right.$ horizon) to very calcareous $(24.6 \%$, $\mathrm{C}_{\mathrm{g} 1}$ horizon). Organic matter was highest in the surface layers and decreased regularly with depth. Organic matter content ranged from very low $\left(0.1 \%, \mathrm{C}_{\mathrm{g} 1}\right.$ horizon) to very high (5.4\%, $\mathrm{A}_{\mathrm{p}}$ horizon). With increasing depth, the organic matter decreased and carbonate content increased-except at the deepest horizon, where it also diminished. The cation exchange capacity varied between $10.4\left(\mathrm{cmol}^{+} / \mathrm{kg}\right)$ and $14.8\left(\mathrm{cmol}^{+} / \mathrm{kg}\right)$. The base saturation was nearly $100 \%$ across the entire profile. The dominance of exchangeable bases was in the order of $\mathrm{Ca}^{2+}>\mathrm{K}^{+}>\mathrm{Mg}^{2+}>\mathrm{Na}^{+}$. The exchangeable calcium in the soil samples achieved a value less than $14\left(\mathrm{cmol}^{+} / \mathrm{kg}\right)$, followed by potassium at $0.8\left(\mathrm{cmol}^{+} / \mathrm{kg}\right)$, magnesium at $0.4\left(\mathrm{cmol}^{+} / \mathrm{kg}\right)$ and sodium at $0.1\left(\mathrm{cmol}^{+} / \mathrm{kg}\right)$. The soil was low in available P and total 
$\mathrm{N}$ contents [4,16]; the available phosphorus contents were between $8.1 \mathrm{mg} / \mathrm{kg}$ and 17.6 $\mathrm{mg} / \mathrm{kg}$, and were classified as deficient.

Table 2. Chemical and physicochemical characteristics of the investigated soil.

\begin{tabular}{|c|c|c|c|c|c|}
\hline & & Ap & Bw & Cg1 & $\mathrm{Cg} 2$ \\
\hline \multicolumn{2}{|c|}{ Depth (cm) } & $0-35$ & $35-83$ & $83-111$ & $>111$ \\
\hline \multicolumn{2}{|c|}{ Bulk density (g/cc) } & 0.90 & 1.24 & 1.46 & n.d. \\
\hline \multicolumn{2}{|c|}{$\begin{array}{c}\text { Texture } \\
\text { (to the touch) }\end{array}$} & Silty loam & Silty loam & Silty loam & Silty loam \\
\hline \multicolumn{2}{|c|}{$\mathrm{C} / \mathrm{N}$ ratio } & 11.4 & 13.5 & n.d. & n.d. \\
\hline \multicolumn{2}{|c|}{$\mathrm{pH}$ (water 1:2.5) } & 7.6 & 7.6 & 8.0 & 8.2 \\
\hline \multicolumn{2}{|c|}{ Electrical conductivity $(\mathrm{dS} / \mathrm{m})$} & 1.49 & 1.91 & 2.38 & 1.14 \\
\hline \multicolumn{2}{|c|}{$\mathrm{CaCO}_{3}$ Content $(\%)$} & 18.2 & 18.8 & 24.6 & 10.5 \\
\hline \multicolumn{2}{|c|}{ Active limestone (\%) } & 13.1 & 15.1 & 12.7 & 11.0 \\
\hline \multirow{6}{*}{$\begin{array}{l}\text { Cation } \\
\text { Exchange } \\
\text { Complex } \\
\left(\mathrm{cmol}^{+} / \mathrm{kg}\right)\end{array}$} & $\mathrm{Ca}^{2+}$ & 13.5 & 10.8 & n.d. & n.d. \\
\hline & $\mathrm{Mg}^{2+}$ & 0.4 & 0.3 & n.d. & n.d. \\
\hline & $\mathrm{K}^{+}$ & 0.8 & 0.3 & n.d. & n.d. \\
\hline & $\mathrm{Na}^{+}$ & 0.1 & 0.1 & n.d. & n.d. \\
\hline & CEC & 14.8 & 11.5 & 10.4 & n.d. \\
\hline & V (\%) & 100 & 100 & n.d. & n.d. \\
\hline
\end{tabular}

The moderate development of recent Gleysols, as studied, suggested an alternation in the accumulation and denudation of fine-earth particles on the soil surface in the Late Holocene. In addition, the observed gleyic layer was an indication of a perched water table (under $83 \mathrm{~cm}$ in this case) that coincided with a reduced matrix. The grey color was the result of the reduction in $\mathrm{Fe}^{3+}$ to $\mathrm{Fe}^{2+}$ due to the lack of oxygen at this depth horizon. It was concluded that the soils could be classified as Gleyic Fluvisol (Calcaric, Humic) according to the World Reference Base for Soil Resources [30], and as Fluventic Haploxerept in the Soil Taxonomy System [31].

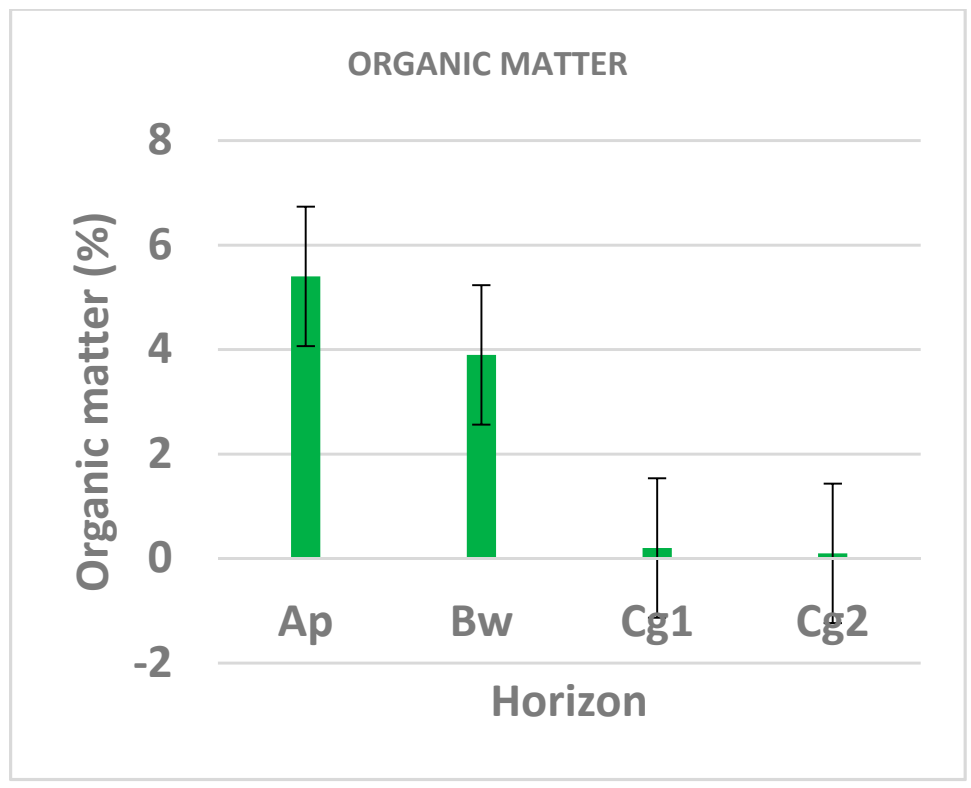

Figure 3. Cont. 

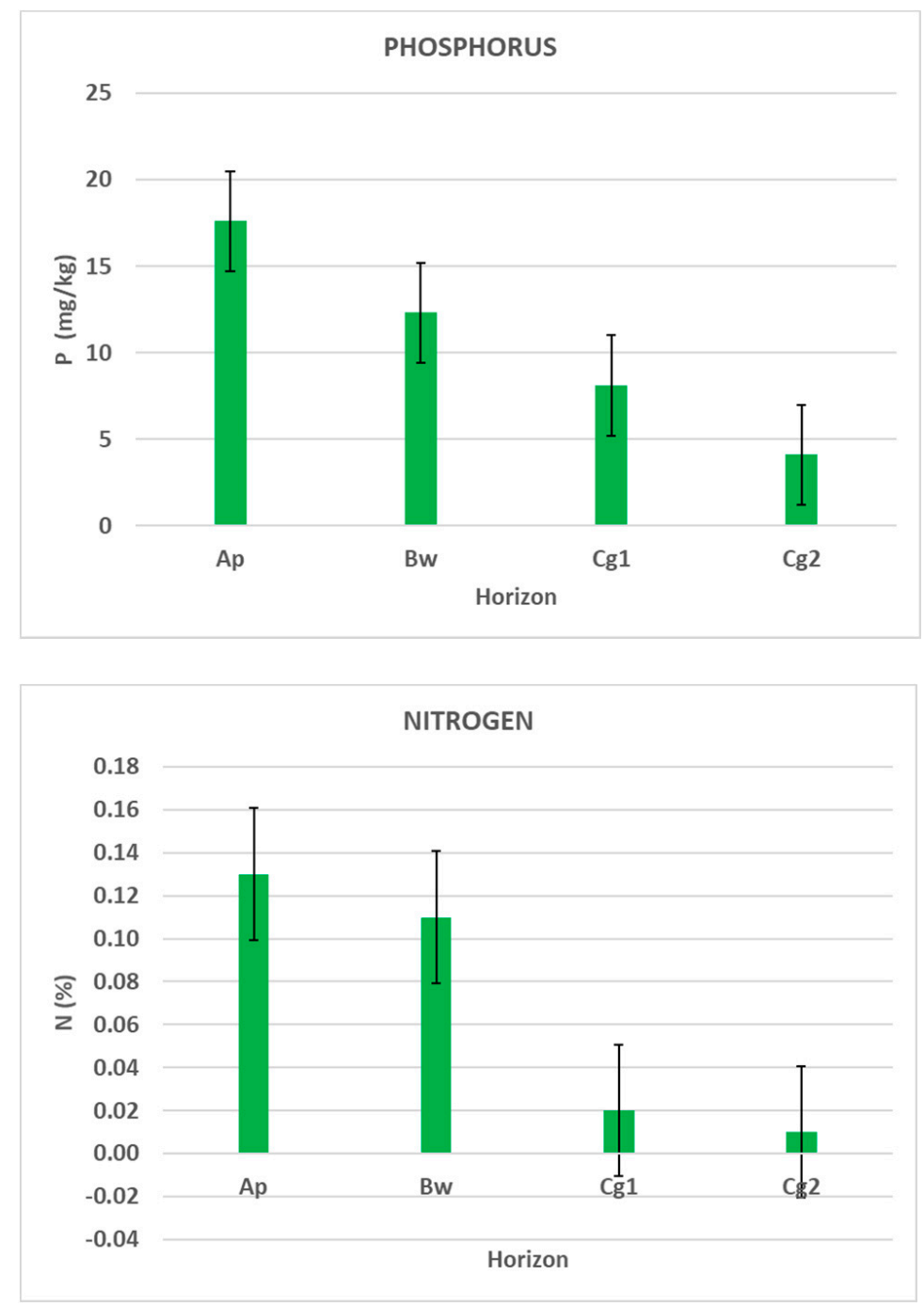

Figure 3. Graphs showing the contents of organic matter, phosphorus and nitrogen.

\section{Discussion}

In the last few decades, the production of wine has notably increased worldwide [32]. Often, production has focused on the creation of new wine-growing areas, as occurred in La Mancha. The soil used-and its characteristics, such as depth, permeability, structure, fertility, acidity, texture, etc. - affects vine root growth and nutrient absorption [3-5,9-17].

According to a previous study carried out by Garcia-Navarro et al. (2018) [20], Alfisols, Inceptisols and Entisols are the main soil types in the Villanueva Alcardete (Toledo) area. Many Alfisols are also called Terra Rossa or red Mediterranean soil, a common name used to indicate soils formed on karst areas in a Mediterranean climate. These soils are characterized by a reddish color ranging from 5YR to 10R Munsell hues, a claylike or silty claylike texture, high internal drainage, and a depth that ranges from a few centimeters to several meters in thickness. When it is not limited by depth and abundant stoniness or rockiness, Terra Rossa is a very fertile soil on which many vineyards are established. Thus, most of the macromorphological, physicochemical and chemical properties of the studied soil imply the designation of a land use system for a vineyard, as appropriate. However, there is a tendency to spread vineyard cultivation to other areas, where this type of soil does not exist, as was the case in the current study. In those cases, hydromorphic features, closely linked to the risks of flooding, combine with certain deficiencies in P and $\mathrm{N}$ to render this type of soil unqualified for use as a vineyard. 
Many soils in Castilla-La Mancha dedicated to vineyards are deficient when it comes to water provision for the proper growth of the vineyard. In fact, the application of drip irrigation has increased because water supply is very important in determining vine survival, growth, root function and fruit quality. However, an excess of humidity seriously damages the vegetative process.

Well-drained soil is essential for the development of grapevine root systems. The accumulation of water implies that all existing gases, particularly oxygen, are displaced. When oxygen disappears from the radicle zone, it can cause problems in cellular respiration, and consequently, the absorption of all nutrients by the roots is affected [16]. A prominent (albeit temporary) deficiency has been documented in the literature, relating to the use of soils affected by a layer of water. The effect of soil anoxia (waterlogging) is an issue that requires considerable study in order to better our understanding of its effects on vine performance.

In soils similar to those described, the appearance of salinity problems due to the accumulation of sodium or magnesium sulfates is to be expected. This salinity can reach dangerous levels when it exceeds $3 \mathrm{dS} / \mathrm{m}$. Vitis vinifera and some rootstocks are sensitive at this level. Other rootstocks, such as 110 Richter or SO4, are more resistant to salinity. If the soil has significant salinity problems (E.C. $>6 \mathrm{dS} / \mathrm{m}$ ), a resistant rootstock, such as 1103 Paulsen, is required [6].

Soil $\mathrm{pH}$ is a significant soil parameter that plays a role in the biotic and abiotic properties of the soil, and especially in the nutrition of vine plants [32]. Generally, in arid and semi-arid regions with high-pH soil, the high calcium ions in the environment react with phosphates, and thus, plants are unable to extract them [33].

In a study conducted by Amoros et al. (2015) in Castilla-La Mancha [4], pH, electric conductivity, organic matter, lime, active limestone, extractable phosphorus, changeable sodium percentage and bulk density were selected as soil quality indicators. The chemical properties of the soil are very important in terms of yield and plant health [4]. Among these chemical properties, lime is an important parameter in terms of determining the usefulness of plant nutrients. The most restricting soil factors for vine growth, generally, are low organic matter, low nutrient content, and salinity. Given that the soil under study had similar or superior properties (e.g., the high content of organic matter) to the majority of soils dedicated to vineyards in Castilla-La Mancha, we were able to advise its use as such. However, given its geomorphological position — with the consequent risk of having gleyic properties-and moderate salinity, it would be advisable to use it for other types of crops.

Some morphological properties, such as the solum thickness and the thickness of the epipedons, and some soil physicochemical properties (clay content, alkaline reaction, calcium and magnesium as the dominant cations followed by sodium and potassium, total nitrogen, carbonate, and exchangeable bases), were similar to those in other soils developed within the area. However, waterlogging affects root and shoot growth and root survival [34-37]. Myburgh [38] observed that the majority of fine grapevine roots in a seasonally waterlogged subsoil were dead when they were observed in late spring. Moreover, salinity's effects on vine performance and berry composition have been studied, albeit mainly in Australia [39,40]. The deleterious effects of salinity on vine growth are caused by an osmotic effect, in which the increase in soluble salt concentration of the soil solution imposes an osmotic drought on the plant, and a toxic effect, whereby the tissue concentrations of the micronutrient chloride and the beneficial element sodium increase to toxic levels [41]. Salinity damage has been a concern for a long time in Australian vineyards [42]. Consequently, land suitability evaluations in this landform (floodplain) have shown that the soil is marginally suitable or unsuitable for vineyard production. Therefore, faced with the sometimes-inappropriate expansion of land dedicated to vineyards, it is important to take these limitations into account. More detailed studies would be helpful for the management of sloping geomorphic surfaces, in particular, those where grapevines share space with fluvial and saline channels. 


\section{Conclusions}

Although individual soils in the landscape commonly merge into one another as their characteristics gradually change, the study conducted on floodplains allowed us to conclude that some subareas of the Cigüela River are unsuitable for vineyards due to their poor drainage conditions. Even though we were not working from knowledge of the ideal soil for wine grape production per se, but rather an ideal set of soil properties for a given climate, the results of this work reveal that the studied soil, despite showing some high-quality properties that are similar to those of many other soils dedicated to vineyard cultivation in Castilla-La Mancha, should not be used for this purpose. The soil factors that would restrict vineyard growth were waterlogging, which can affect grapevine roots, and the appearance of certain salinity problems. The results of this study, which have implications for increasing the acreage dedicated to vineyards, could be very instructive not only on a regional scale, but also nationally and internationally. The use of the studied soil type for vineyard cultivation could be recommended to farmers only in the case of improving soil properties-for example, draining the river level.

Author Contributions: R.J.-B. conceived and designed this study; F.J.G.-N., R.J.-B., C.P.-d.-1.-R., J.G.-P., M.S. and J.A.A. participated in the collection of soil samples; software, S.B.; formal analysis, J.G.-P. and M.S.; writing-original draft preparation, R.J.-B., F.J.G.-N., C.P.-d.-l.-R., J.A.A. and S.B. All authors have read and agreed to the published version of the manuscript.

Funding: This research was funded by “Denominación de origen Uclés” (Denomination of Origin), grant number UCTR140234.

Institutional Review Board Statement: Not applicable.

Informed Consent Statement: Not applicable.

Data Availability Statement: Data was obtained from Uclés Denomination of Origin (D.O.) and are available from the authors with the permission of Uclés D.O.

Acknowledgments: The authors acknowledge the financial support given by the "Denominación de Origen Uclés" (Denomination of Origin) and the farmers of the region.

Conflicts of Interest: The authors declare no conflict of interest.

\section{References}

1. Hualin, X.; Yingqian, H.; Qianru, C.; Yanwei, Z.; Qing, W. Prospects for Agricultural Sustainable Intensification: A Review of Research. Land 2019, 8, 1-27.

2. Yaalon, D.H. Soils in the Mediterranean region: What makes them different? Catena 1997, 28, 157-169.

3. Jiménez-Ballesta, R.; Bravo, S.; Amorós, J.A.; Pérez-de los Reyes, C.; García-Pradas, J.; García-Navarro, F.J. Understanding the Quality of Local Vineyard Soils in Distinct Viticultural Areas: A Case Study in Alcubillas (La Mancha, Central Spain). Agriculture 2020, 10, 66. [CrossRef]

4. Amorós, J.A.; Bravo, S.; García-Navarro, F.J.; Pérez-de-los-Reyes, C.; Chacón, J.L.; Martínez, J.; Jiménez-Ballesta, R. Atlas de Suelos de Castilla-La Mancha, 1st ed.; Globalcaja and Universidad de Castilla-La Mancha: Ciudad Real, Spain, 2015; p. 318.

5. Jiménez-Ballesta, R.; Pérez-De-Los-Reyes, C.; Amorós, A.; Bravo, S.; García-Navarro, F.J. Pedodiversity in Vineyards of CastillaLa Mancha, Spain. In Proceedings of the XII Congreso Internacional Terroir, Zaragoza, Spain, 18-22 June 2018; Volume 50, pp. 324-328, ISBN 978-84-09-03040-8.

6. MAPA. Ministerio de Agricultura, Ganadería y Pesca. Anuario de Estadística Agraria y Alimentaria. 2019. Available online: https://www.mapa.gob.es/es/estadistica/temas/publicaciones/anuario-de-estadistica/default.aspx (accessed on 26 September 2020).

7. Sugár, E.; Fodor, N.; Sándor, R.; Bónis, P.; Vida, G.; Árendás, T. Spelt Wheat: An Alternative for Sustainable Plant Production at Low N-Levels. Sustainability 2019, 11, 6726. [CrossRef]

8. Dubey, R.K.; Dubey, P.K.; Chaurasia, R.; Rao, C.S.; Abhilash, P.C. Impact of Integrated Agronomic Practices on Soil Fertility and Respiration on the Indo-Gangetic Plain of North India. Agronomy 2021, 11, 402. [CrossRef]

9. Morlat, R.; Jacquet, A. The Soil Effects on the Grapevine Root-System in Several Vineyards of the Loire Valley (France). VITIS 1993, 32, 35-42.

10. Van Leeuwen, C.; Friant, P.; Choné, X.; Tregoat, O.; Koundouras, S.; Dubourdieu, D. Influence of climate, soil, and cultivar on terroir. Am. J. Enol. Vitic. 2004, 55, 207-217. 
11. Lanyon, D.; Cass, A.; Hansen, D. The Effect of Soil Properties on Vine Performance; Technical Report; CSIRO Land and Water: Adelaide, Australia; Clayton, Australia, 2004; p. 54.

12. Greenough, J.D.; Mallory-Greenough, L.M.; Fryer, B.J. Geology and wine 9: Regional trace element fingerprinting of Canadian wines. Geosci. Can. 2005, 32, 129-137.

13. De Andres-De-Prado, R.; Yuste-Rojas, M.; Sort, X.; Andres-Lacueva, C.; Torres, M.; Lamuela-Raventos, R.M. Effect of soil type on wines produced from Vitis vinifera L. cv Grenache in commercial vineyards. J. Agric. Food Chem. 2007, 55, 779-786. [CrossRef]

14. Wang, R.; Sun, Q.; Chang, Q. Soil Types Effect on Grape and Wine Composition in Helan Mountain Area of Ningxia. PLoS ONE 2015, 10, e0116690. [CrossRef]

15. Jiménez-Ballesta, R.; Bravo, S.; Amorós, J.A.; Pérez-de los Reyes, C.; García-Pradas, J.; Sánchez Ormeño, M.; García-Navarro, F.J. Soil Genesis and Vineyard Suitability for Viticulture in Zones under Mediterranean Environment. Eurasian Soil Sci. 2021, 54, 1152-1160. [CrossRef]

16. White, R.E. Understanding Vineyard Soils, 2nd ed.; Oxford University Press: Oxford, UK, 2009; p. 280.

17. Seguin, G. "Terroirs" and pedology of wine growing. Experientia 1986, 42, 861-873. [CrossRef]

18. Walia, C.; Chamuah, S. Characteristics, classification and suitability for land use planning of foothill soils. J. Indian Soc. Soil Sci. 1990, 38, 286-292.

19. Brubaker, S.C.; Gones, A.J.; Lewis, D.T.; Frank, K. Soil properties associated with landscape position. Soil Sci. Soc. Am. J. 1993, 57, 235-239. [CrossRef]

20. Garcia-Navarro, F.J.; Amorós, J.A.; Pérez-De-Los-Reyes, C.; García-Pradas, J.; Bravo, S.; Jiménez-Ballesta, R. Informe sobre los Suelos de la Cooperativa San Isidro. Villanueva de Alcardete (Toledo); Denominación de Origen Uclés; DO Uclés-UCLM: Ciudad Real, Spain, 2018.

21. FAO. Guidelines for Soil Description, 4th ed.; FAO/UNESCO: Rome, Italy, 2006; p. 108.

22. International Organization for Standardization, Geneva. ISO 10390:2005: Soil Quality—Determination of pH. 2005. Available online: https: / / www.iso.org/standard/40879.html (accessed on 16 September 2021).

23. Nelson, D.W.; Sommers, L.E. Total Carbon, Organic Carbon and Organic Matter; ASA-SSSA: Madison, WI, USA, $1982 ;$ pp. 539-579.

24. Bremner, J.M.; Mulvaney, C.S. Nitrogen Total. In Methods of Soil Analysis Part 2, Chemical and Microbiological Properties; ASA-SSSA: Madison, WI, USA, 1982; pp. 621-622.

25. Drouineau, G. Dosage rapide du calcaire actif de sols. Ann. Agron. 1942, 12, 441-450.

26. Thomas, G.W. Exchangeable Cations. In Methods of Soil Analysis, Part 2; ASA-SSSA: Madison, WI, USA, $1982 ;$ pp. $159-165$.

27. Olsen, S.R.; Cole, C.V.; Watanabe, F.S.; Dean, L.A. Estimation of Available Phosphorus in Soils by Extraction with Sodium Bicarbonate; USDA: Washington, DC, USA, 1954; p. 22.

28. Blake, G.R.; Hartge, K.H. Bulk density. In Methods of Soil Analysis, Part 1: Physical and Mineralogical Methods, 2nd ed.; ASA-SSSA: Madison, WI, USA, 1986; pp. 363-382.

29. Leake, S. Soils for Olive Planting: Choosing and Improving. Sydney, Sydney Environment, Soil Laboratory Pty Ltd. 2001. Available online: http:/ / www.sesl.com.au/uploads/articles/Soils_for_Olive_Planting.pdf (accessed on 11 September 2019).

30. IUSS Working Group WRB. World Reference Base for Soil Resources: International Soil Classification System for Naming Soils and Creating Legends for Soil Maps; World Soil Resources Reports No. 106; FAO: Rome, Italy, 2015.

31. Soil Survey Staff. Key to Soil Taxonomy, 12th ed.; USDA-Natural Resources, Conservation Service: Washington, DC, USA, $2014 ;$ p. 379.

32. Bravo, S.; Amorós, J.A.; Pérez-De-Los-Reyes, C.; García, F.J.; Moreno, M.M.; Sánchez-Ormeño, M.; Higueras, P. Influence of the soil $\mathrm{pH}$ in the uptake and bioaccumulation of heavy metal ( $\mathrm{Fe}, \mathrm{Zn}, \mathrm{Cu}, \mathrm{Pb}$ and $\mathrm{Mn}$ ) and other elements $(\mathrm{Ca}, \mathrm{K}, \mathrm{Al} \mathrm{Sr}$ and $\mathrm{Ba})$ in vine leaves, Castilla-La Mancha (Spain). J. Geochem. Explor. 2017, 174, 79-83. [CrossRef]

33. Sanyal, S.K.; De Datta, S.K. Chemistry of phosphorus transformation in soils. In Advances in Soil Science; Springer: Berlin/Heidelberg, Germany, 1991; Volume 16, pp. 1-94.

34. Kobayashi, A.; Iwasaki, K.; Sato, Y. Growth and nutrient absorption of grapes as affected by soil aeration. 1. With non-boaring Delaware grapes. J. Jpn. Soc. Hortic. Sci. 1963, 32, 33-37. [CrossRef]

35. Iwasaki, K.; Kadoya, K.; Kuraoka, T. Growth and nutrient adsorption of Dalaware grapes as affected by soil oxygen. IV. Comparison of the effect among different soil properties. J. Jpn. Soc. Hortic. Sci. 1966, 35, 15-22. [CrossRef]

36. Myburgh, P.A.; Moolman, J.H. Ridging-a soil preparation practice to improve aeration of vineyard soils. S. Afr. J. Plant Soil 1991, 8, 189-193. [CrossRef]

37. Myburgh, P.A.; Moolman, J.H. The effect of ridging on the soil water status of a waterlogged vineyard soil. S. Afr. J. Plant Soil 1991, 8, 184-188. [CrossRef]

38. Myburgh, P.A. Effect of ridging on the performance of young grapevines on a waterlogged soil. S. Afr. J. Enol. Vitic. 1994, 15, 3-8. [CrossRef]

39. Stevens, R.M.; Harvey, G.; Partington, D.L. Irrigation of grapevines with saline water at different growth stages: Effects on leaf, wood and juice composition. Aust. J. Grape Wine Res. 2011, 17, 239-248. [CrossRef]

40. Walker, R.R.; Blackmore, D.H.; Clingeleffer, P.R.; Emanuelli, D. Rootstock type determines tolerance of Chardonnay and Shiraz to long-term saline irrigation. Aust. J. Grape Wine Res. 2014, 20, 496-506. [CrossRef]

41. Marschner, H. Mineral Nutrition of Higher Plants; Academic Press: London, UK, 1986.

42. Hickinbotham, A.R.; Williams, R.A. Soluble salts in non-irrigated vineyards. S. Aust. J. Agric. 1933, 36, $217-223$. 